\title{
16. GEOCHEMISTRY AND MINERALOGY OF IRON- AND TRACE-METAL-RICH MESSINIAN AND PLIOCENE MUDSTONES CORED ON THE SARDINIAN MARGIN: ODP LEG 107, TYRRHENIAN SEA (CENTRAL MEDITERRANEAN) ${ }^{1}$
}

\author{
A.H.F. Robertson ${ }^{2}$
}

\begin{abstract}
Brightly colored mudstones within Messinian (late Miocene) and lower Pliocene successions were cored beneath the upper and lower slopes of the Sardinian continental margin of the Tyrrhenian Sea (Central Mediterranean). A total of 24 samples were analyzed for major and trace elements and 20 samples were studied by whole-rock X-ray diffraction. The colorful sediments studied include millimeter-thick limonitic laminations within coarser-grained clastic sedimentary rocks (Site 652) and local ferruginous zones near the top of the Messinian succession elsewhere (Site 653). The basal Pliocene metalliferous sediments comprise up to several tens of meters of colorful, mainly red, yellow, and brown, calcareous clays at the base of nannofossil-rich Pliocene deep-sea sediment successions (Sites 652, 653, 654).

Relative to average shale, the Messinian mudstones cored on the de Marchi seamount, the lowest rift fault block on the Sardinian margin (Site 656), are notably enriched in lead ( $\mathrm{Pb})$, zinc $(\mathrm{Zn})$, and to a lesser extent, in copper $(\mathrm{Cu})$ and nickel $(\mathrm{Ni})$, and are associated with local clasts of sulfide ore. Messinian sediments higher on the Sardinian margin (Cornaglia Terrace, Site 653) are enriched in $\mathrm{Zn}$ and $\mathrm{Pb}$. The basal Pliocene sediments, particularly at Site 653, are strongly enriched in iron $(\mathrm{Fe})$, manganese $(\mathrm{Mn}), \mathrm{Pb}$ and $\mathrm{Zn}$, relative to the overlying Pliocene nannofossil oozes. This $\mathrm{Fe}$ and Mn enrichment is believed to have resulted from oxidation under hot arid conditions in the Messinian, followed by reworking of insoluble metal oxides during the Pliocene transgression that ensued. $\mathrm{The} \mathrm{Pb}$ and $\mathrm{Zn}$ were apparently associated with sulfide ore, of either volcanic-hosted (?Mesozoic) Kuroko-type or (?Tertiary rift-related) sediment-hosted Mississippi-type. The $\mathrm{Fe}$ and $\mathrm{Mn}$ oxides and insoluble ore material were later reworked, leading to a marked $\mathrm{Pb}-\mathrm{Zn}$ metal anomaly in ferruginous basal Pliocene sediments.
\end{abstract}

\section{INTRODUCTION}

Eye-catching, brightly colored, fine-grained sediments were cored in late Miocene and Pliocene successions on the Sardinian passive margin in the Tyrrhenian Sea (western Mediterranean) during Ocean Drilling Program (ODP) Leg 107 (Figs. 1 and 2). On the lower Sardinian margin, colorful Messinian sediments range from millimeter-thick red, yellow, and orange laminations in clastic and evaporitic sediments (Site 652), to ferruginous oxide segregations high in the Messinian succession elsewhere (Holes $653 \mathrm{~A}$ and 653B). Reddish muds of presumed Messinian age also locally overlie the de Marchi seamount, the lowest rotated fault block of continental crust at the base of the rifted Sardinian margin. In addition, brownish and reddish nannofossil-rich clays were studied from the base of the Pliocene succession on both the upper and lower Sardinian margins (Sites 652, 653, 654).

The Tyrrhenian Sea began to form in late Miocene time by the rifting of Calabria from Sardinia and Corsica (Fig. 1). Rifting gave way to the emplacement of marginal and/or transitional ocean crust during Pliocene time, related to irregular spreading above a northwestward-dipping subduction zone (Kastens, Mascle, Auroux, et al., 1987; Kastens, Mascle, et al., 1988). Based on this study, one might argue that the main control of metal enrichment was paleoenvironmental change related to the Messinian salinity crisis (Hsü et al., 1978), combined with the tectonics of rifting and continental breakup.

\section{ANALYTICAL PROCEDURE}

A representative suite of brightly colored mudstones was analyzed for mineral content by whole-rock X-ray diffraction $(\mathrm{Cu}$

\footnotetext{
${ }^{1}$ Kastens, K. A., Mascle, J., et al., 1990. Proc. ODP, Sci. Results, 107: College Station, TX (Ocean Drilling Program).

2 Department of Geology, University of Edinburgh, Edinburgh EH9 3JW, United Kingdom.
}

$\mathrm{K} \alpha$ radiation, Table 1). A total of 24 samples were selected for shore-based analysis for major and trace elements by X-ray fluorescence, using the method developed by Fitton and Dunlop (1985).

The near-basal Pliocene sediments are discussed in order of site occupation, and then compared with brightly colored Messinian sediments from two sites (Sites 652 and 656).

\section{Basal Pliocene Sediments, Lower Sardinian Slope: Site $\mathbf{6 5 2}$}

Five analyzed samples are composed of yellowish mottled, brown and brownish yellow, yellowish red, and dark gray muds of lower Pliocene age that occur within $14 \mathrm{~m}$ of the underlying Messinian succession (contact at 107-652R-6R, $20 \mathrm{~cm}$ ). The overlying later Pliocene succession is made up of grayish, greenish, and olive-colored marly nannofossil oozes. By contrast, the underlying Messinian sediments mainly consist of turbiditic gypsum-bearing sandy and silty clay and calcareous mudstone (Fig. 2).

\section{Mineralogy}

Shipboard smear-slide analysis of the mudstone revealed clay with local calcite, subordinate planktonic foraminifers, and nannofossils, and minor accessory minerals, bioclasts, and micrite. Compositions corresponding to an estimated $25 \%$ of volcanic glass were reported in three smear slides from one core (107652A-19R).

$\mathrm{X}$-ray diffraction reveals abundant quartz, goethite, calcite, dolomite, illite, chlorite, halite, feldspar, and mixed-layer clays (Table 1). Samples lower in the succession contain generally greater abundances of quartz, goethite, and dolomite, while calcite is more abundant stratigraphically higher.

\section{Geochemistry}

All the samples are siliceous and aluminous, reflecting a dominantly terrigenous background and fine-grained sediment 


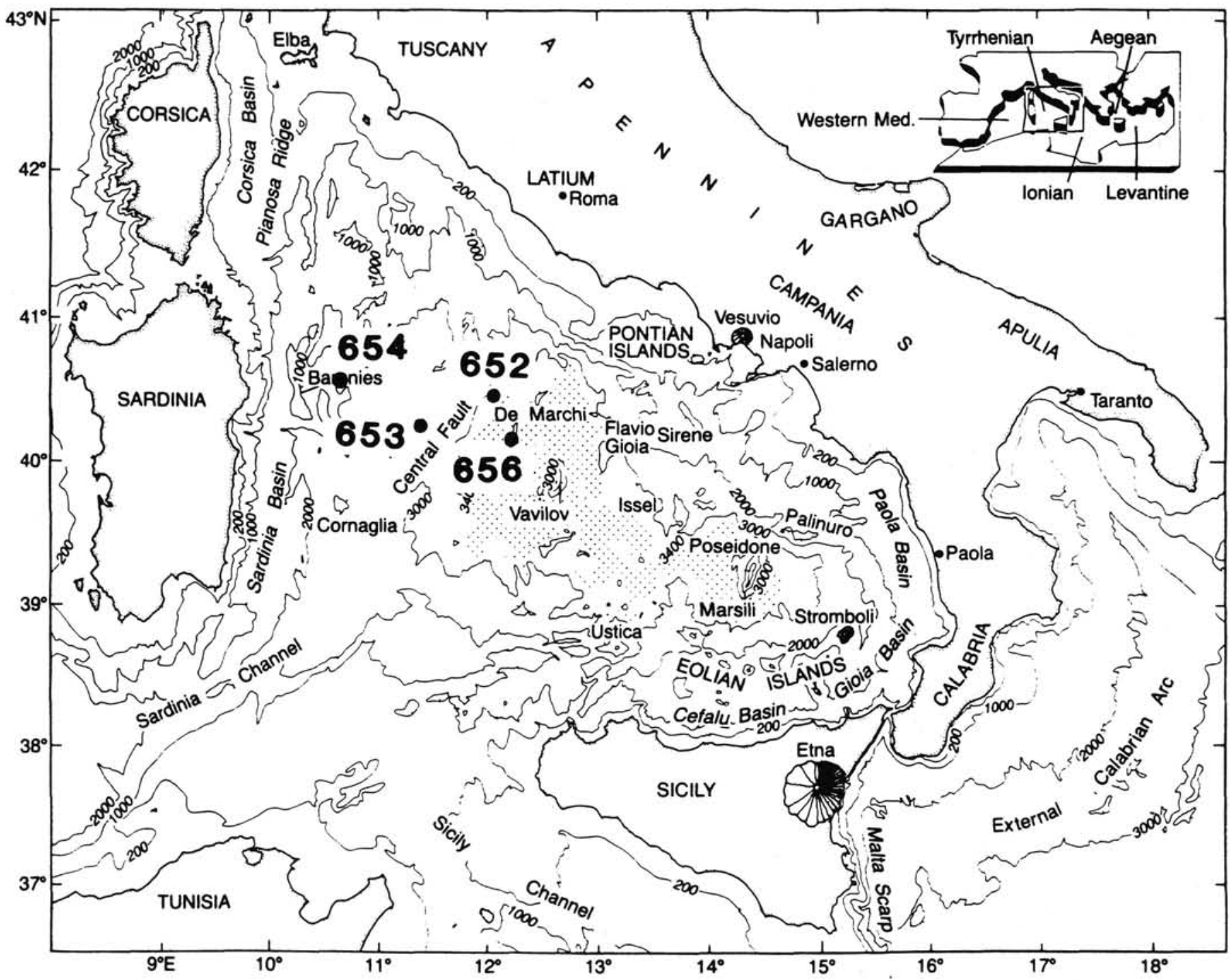

Figure 1. Bathymetric map showing locations of sites sampled in the Tyrrhenian Sea.

influx. Samples become progressively more aluminous upward, possibly reflecting increasing clay mineral and feldspar contents $\left(\mathrm{Al}_{2} \mathrm{O}_{3}, 7.11 \%-12.10 \%\right.$; Table 2$)$. All the samples are ferruginous, especially lower in the interval $\left(\mathrm{Fe}_{2} \mathrm{O}_{3} ; 20.20 \%\right)$. MgO levels are constant, while $\mathrm{K}_{2} \mathrm{O}$ fluctuates more widely, increasing upward, possibly correlating with the increased amount of illite detected by X-ray diffraction. All the samples are calcareous ( $\mathrm{CaO}$ up to $49.06 \%)$. $\mathrm{TiO}_{2}$ shows no systematic variation; levels are typical of shales and deep-sea clays generally (Turekian and Wedhepohl, 1961). MnO values are strongly enriched relative to deep-sea clays throughout, most notably lower in the analyzed interval (maximum $1.98 \%$ ). $\mathrm{P}_{2} \mathrm{O}_{5}$ values show no systematic variation in any of the samples analyzed from the Tyrrhenian Sea.

The trace-element values lie in the range of average shale and are depleted relative to average deep-sea clay (e.g., Ni, Cu; Turekian and Wedhepohl, 1961). Barium (Ba) levels are high, corresponding to $\mathrm{Fe}_{2} \mathrm{O}_{3}$ content.

The mainly terrigenous-derived trace elements (chromium $[\mathrm{Cr}]$, zirconium $[\mathrm{Zr}]$, and rubidium [Rb]) typically are near average shale in composition (although $\mathrm{Rb}$ is $50 \%$ above the average shale value). Barium levels are closer to those of average shale $(580 \mathrm{ppm})$ than deep-sea clay $(2300 \mathrm{ppm})$. Copper values are typical of shale, except for one sample that is markedly en- riched (212 ppm; Table 2). By contrast, levels of $\mathrm{Zn}$ and $\mathrm{Pb}$ are strongly enriched relative to average shale and deep-sea clay ( $\mathrm{Zn}$ up to $470 \mathrm{ppm}$; $\mathrm{Pb}$ up to $420 \mathrm{ppm}$ ). Average $\mathrm{Pb}$ values are 22 $\mathrm{ppm}$ in shale and $60 \mathrm{ppm}$ in deep-sea clay (Turekian and Wedhepohl, 1961).

\section{Interpretation}

The brightly colored basal Pliocene sediments overlying the Messinian evaporitic sediments are calcareous and clay-rich deepsea sediments of near average shale composition. Shale, rather than oceanic clay, composition is consistent with rapid accumulation of these lower Pliocene sediments following transgression of the Messinian land surface to form a small ocean basin. On the other hand, these basal sediments are markedly enriched in $\mathrm{Fe}, \mathrm{Mn}, \mathrm{Zn}$, and $\mathrm{Pb}$. In theory, the Fe-Mn enrichment could be attributed to (1) slow condensed accumulation from seawater, (2) upward diagenetic mobilization from underlying reducing Messinian sediments, or (3) a detrital particulate origin. Alternatives are discussed in a later section.

\section{Lower Pliocene Sediments on the Cornaglia Terrace, Site 653}

Four samples of metalliferous sediment were analyzed from Hole $653 \mathrm{~B}$, located on the Cornaglia Terrace on the mid-part of 

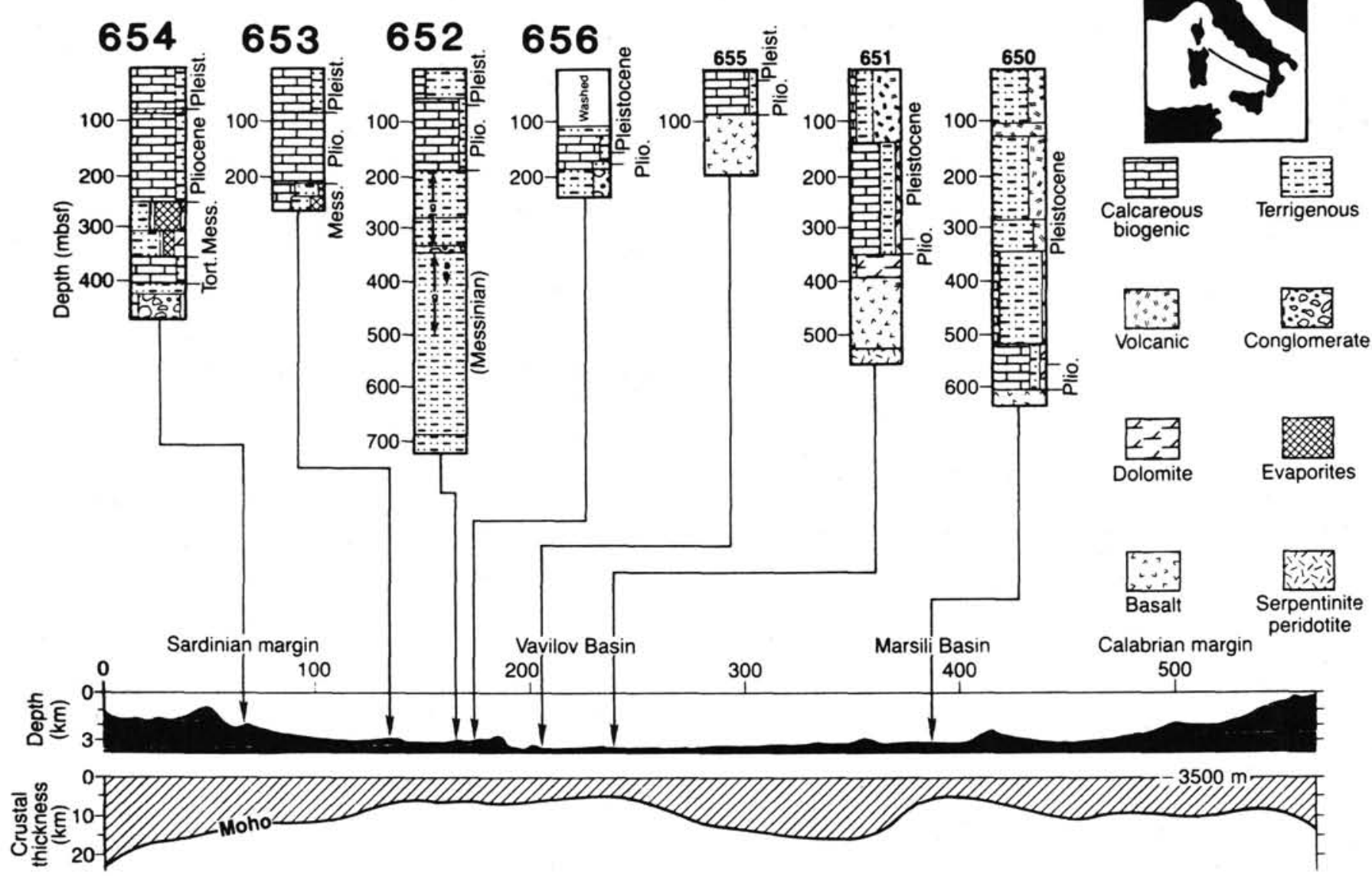

Figure 2. Simplified logs of the successions drilled during Leg 107 in the Tyrrhenian Sea. The sediments analyzed come from just above the Miocene/ Pliocene boundary at Sites 652, 653, and 654. Colorful Messinian sediments also were analyzed from Sites 654 and 656.

Table 1. Summary of X-ray diffraction data ${ }^{1}$ for analyzed samples.

\begin{tabular}{|c|c|c|c|}
\hline $\begin{array}{l}\text { Core, section, } \\
\text { interval }(\mathrm{cm})\end{array}$ & $\begin{array}{l}\text { Major } \\
\text { component }\end{array}$ & $\begin{array}{c}\text { Minor } \\
\text { component }\end{array}$ & $\begin{array}{c}\text { Trace } \\
\text { component }\end{array}$ \\
\hline $107-650-2 \mathrm{R}-3,50-51$ & Qtz & Cal Hal Feld & Ill Chl Anhyd \\
\hline $652-4 R-5,40-45$ & Cal Qtz & IIl Kaol & Chl Feld \\
\hline $6 \mathrm{R}-1,40-42$ & Qtz & IIl Pyr Hal & Chl Dol Feld \\
\hline $64 X-1,23-24$ & Dol Qtz & III Chl & Feld Kaol \\
\hline $64 X-1,103-104$ & Qtz & Dol Pyr Chl & III Smect \\
\hline $653-7 R-4,29-31$ & Cal Qtz & Pyr III & Hal Chl Kaol Gyp Dol Feld \\
\hline $8 \mathrm{R}-1,4-6$ & Cal Qtz & III & Chl Kaol Hal Feld \\
\hline $8 \mathrm{R}-1,8-10$ & Cal Qtz & III & Pyr Chl Hal Kaol Smect \\
\hline $654-6 R-4,50-51$ & Cal & Qtz & Hal Kaol Chl Feld \\
\hline $6 \mathrm{R}-4,142-144$ & Cal Qtz & Pyr III & Chl Kaol \\
\hline $38 \mathrm{R}-1,126-132$ & $\mathrm{Cal}$ & Qtz Pyr & III \\
\hline $39 \mathrm{R}-2,6-9$ & Dol Qtz & Pyr Hal & Gyp III Chl Feld Smect \\
\hline
\end{tabular}

'(analyst, G. R. Angell)

Anhyd $=$ anhydrite, $\mathrm{Cal}=$ calcite, $\mathrm{Chl}=$ chlorite, $\mathrm{Dol}=$ dolomite, Feld $=$ feld spar, $\mathrm{Gyp}=$ gypsum, $\mathrm{Hal}=$ halite, $\mathrm{Ill}=$ illite, $\mathrm{Kaol}=$ kaolinite, $\mathrm{Pyr}=$ pyrite Smect $=$ smectite and mixed layer clays, and $\mathrm{Qtz}=$ quartz

the Sardinia passive margin (Figs. 1,2; Table 3). Three were from the Messinian interval and one from the overlying basal Pliocene interval. The Messinian sediments comprise yellow, olive gray, and red claystone. The Pliocene samples consist of reddish brown nannofossil ooze, located $6 \mathrm{~m}$ above the Messinian/ Pliocene boundary (at the base of Core 107-653B-23X). The ba- sal $12 \mathrm{~m}$ of the Pliocene sediments are stained yellow and orange and then grade into typical gray, greenish, and olive Pliocene nannofossil ooze.

\section{Mineralogy}

Smear slides of the Messinian sediments in the two cores examined on board ship (107-653B-27X and 28X) revealed clay, quartz, dolomite, limonite, gypsum, anhydrite, opaque oxide grains, accessory minerals, localized nannofossils, and planktonic foraminifers. The Pliocene sediment comprises abundant clay, nannofossils, planktonic foraminifers, quartz, minor micrite, radiolarians, limonite, gypsum, and opaque mineral grains.

X-ray diffraction of a Messinian sample (Table 1) revealed quartz, gypsum, feldspar, and illite, with minor chlorite and kaolinite. By contrast, a Pliocene sample is composed of quartz hematite, goethite, gypsum, and minor illite, chlorite, feldspar, and kaolinite. This sample also contains small white particles within a reddish matrix. The two sediment types were analyzed separately. The reddish background sediment matrix is made up of quartz, hematite, chlorite, and minor illite, feldspar, and kaolinite, while only gypsum and quartz were detected in the pale material (Table 1).

\section{Chemistry}

The Messinian and Pliocene sediments are similarly aluminous and siliceous, reflecting a constant terrigenous influx during both late Miocene and early Pliocene. The high aluminaand magnesian-rich nature of one sample corresponds to an 
abundance of feldspar and illite detected by X-ray diffraction. The samples are all ferruginous and reach $53.26 \% \mathrm{Fe}_{2} \mathrm{O}_{3}$ in the upper of the Messinian samples analyzed (Table 3). $\mathrm{CaO}$ values are low in the Messinian sediments (maximum $7.42 \%$ ), but much higher in the Pliocene $(36.47 \%$ ), reflecting calcareous microfossil content. Levels of $\mathrm{K}_{2} \mathrm{O}$ are lower than in the Messinian sediments. $\mathrm{MnO}$ values are also low in the Messinian sediments, similar, or lower than, average shale $(0.085 \%$; Turekian and Wedhepohl, 1961). By contrast, the Pliocene sediments are very enriched in $\mathrm{MnO}$ relative to deep-sea clay, as noted at Site 652 .

Of the trace elements, all are within the ranges of average shale, with the exception of strong enrichment in $\mathrm{Zn}$ (372 ppm) and $\mathrm{Pb}(756 \mathrm{ppm})$ in the lower Pliocene sample.

\section{Interpretation}

Lithogenous influx to the Messinian sediments studied was continentally derived. Petrology and sedimentary structures suggest that the Messinian intervals of Holes 533A and 533B accumulated in a sabhka setting (Kastens, Mascle, Auroux, et al., 1987). The pronounced $\mathrm{Fe}$ enrichment reflects strong oxidation. In modern evaporitic areas (Shearman, 1982), as around the desert shores of the Great Salt Lake, Utah, limonitic sediments are precipitated from springs where very saline and more normal salinity groundwaters mix (Hardie et al., 1978; McKenzie et al., 1980). Such springs could be the source of the strong iron oxide enrichment in the Messinian sediments analyzed. Extremely low $\mathrm{MnO}$ levels then possibly reflect iron oxide precipitation following evaporation of reducing ?sulfide-rich groundwaters. By contrast, the Pliocene sediments are similar to terrigenous shale, apart from, once again, a striking enrichment in $\mathrm{MnO}, \mathrm{Zn}$, and $\mathrm{Pb}$ (see below).

\section{Messinian and Pliocene Sediments on the Upper Sardinian Margin: Site 654}

Three samples of brightly colored mudstones were analyzed from the lower Pliocene interval of the upper Sardinian margin (Figs. 1 and 2). The Messinian sample comprises greenish silty clay. The two lower Pliocene samples consist of olive to olive brown burrowed nannofossil ooze.

Smear slides of the Messinian sediment (107-654-28R) reveal clay, feldspar, quartz, micrite, gypsum, dolomite, and minor accessory minerals. The Pliocene sediments are composed of nannofossils, planktonic foraminifers, clay, quartz, dolomite, sulfide minerals, traces of volcanic glass, and accessory minerals.

X-ray diffraction of the Messinian sediment confirms the presence of calcite, quartz, and minor dolomite, illite, kaolinite, chlorite, and halite. The Pliocene sediments are made up of calcite and quartz, with subordinate kaolinite and feldspar and minor amounts of illite, chlorite, feldspar, dolomite, and halite (Table 1).

Major- and trace-element chemistry (Table 4) shows that the Messinian sample is again effectively terrigenous clay. However, levels of $\mathrm{Zn}(353 \mathrm{ppm})$ and $\mathrm{Pb}(130 \mathrm{ppm})$ are well above average shale values (95 ppm and $20 \mathrm{ppm}$, respectively; Turekian and Wedhepohl, 1961). The most notable feature of the lower Pliocene sediment is its strong enrichment in $\mathrm{Fe}_{2} \mathrm{O}_{3}$ (up to $14.96 \%$ ), $\mathrm{MnO}$ (up 2.25\%), and $\mathrm{Zn}$ and $\mathrm{Pb}$ (up to $1196 \mathrm{ppm}$ and 1041 ppm, respectively).

\section{Interpretation}

The $\mathrm{Pb}$ and $\mathrm{Zn}$ enrichment at Site 654 occurs in the Messinian as well as the Pliocene intervals; possible explanations are discussed later.

\section{Messinian Sediments on the Continental de Marchi Seamount, Lower Sardinian Margin: Site 656}

Eight more samples of colorful sediments were analyzed from the unfossiliferous basal (inferred Messinian) interval of
Holes 656A and 656B, the site of a tilted rift fault block at the base of the lower Sardinian margin near the Vavilov Basin (Fig. 1). Dredging (Heezen et al., 1971; Colantoni et al., 1961) and submersible study (Gennesseux et al., 1986) farther southeast on the steeper east flank revealed Paleozoic and Mesozoic sedimentary and low-grade metamorphic rocks (Sartori et al., 1987).

The sediments analyzed comprise reddish, brown, and gray metal-rich silty claystones. The samples in Hole 656A come from a core (107-656A-9R) that contains pebbles of siltstone, sandstone, dolomitic marl, dolomite, red chert, silicified micritic limestone, altered greenstone, crystalline sulfides, tremolite-rich metagabbro, metasedimentary rocks, and numerous red mudstone intraclasts. Clasts of crystalline massive sulfide are also present (?galena, pyrite, and chalcopyrite). Samples from Hole 656B (107-656B-6R and -8R) are associated with calcareous sandy mud, dolomitic sandstone, mudstone and (slumped) nannofossil-rich calcareous ooze, limonitic mud, and sandstone (Kastens, Mascle, Auroux, et al., 1987).

\section{Mineralogy}

Smear slides reveal clay, quartz, limonite and/or hematite, calcite, dolomite, mica, clay, feldspar, and micrite. Accessory minerals include possible zeolites, volcanic glass, gypsum, pyroxene, and sphene.

$\mathrm{X}$-ray diffraction (Table 1) of samples from Hole 656A reveals abundant quartz, with subordinate dolomite, hematite, calcite, and minor anhydrite, kaolinite, chlorite, feldspar, and halite. In Sample 107-656A-9R-2, 138-139 cm (Table 1), red and gray mottles were analyzed separately. The red patch contains quartz, dolomite, hematite, goethite, and minor feldspar, kaolinite, chlorite and illite, while the adjacent gray patch contains dolomite, chlorite, illite, and traces of mixed-layer clays only. Similarly, gray, red, and white mottles were again analyzed separately in another sample (107-656A-9R-3, 77-79 cm; Table 1). Distinct differences again exist. The red patch contains quartz, dolomite, hematite, goethite, kaolinite, illite, feldspar, and mixedlayer clays, in approximately decreasing abundance. The gray patch is similar but also contains detectable chlorite. By contrast, the white patch contains only chlorite and quartz. One other sample (107-656A-9R-6, 105-107 cm) was found to contain quartz, dolomite, and kaolinite. Hard, white mineral grains in this sample were analyzed separately and identified as magnesite.

\section{Chemistry}

Like the Messinian sediments discussed earlier, a continental source is indicated. Several samples are extremely ferruginous (up to $30.50 \%$ ), reflecting the high hematite and goethite contents, as detected by X-ray diffraction. The mudstones are only moderately calcareous $(\mathrm{CaO} 4.13 \%-14.44 \%) . \mathrm{K}_{2} \mathrm{O}$ varies within a narrow range $(1.68 \%-2.65 \%)$. $\mathrm{MnO}$ values are greatly above normal shale values $(0.38 \%-1.27 \%$; Table 5).

Of the trace elements, $\mathrm{Ba}$ reaches values higher than most of the other Messinian and Pliocene sediments analyzed (up to 606 ppm). Chromium and zirconium contents are constant. All the samples are strongly enriched in $\mathrm{Pb}$ (up to $1040 \mathrm{ppm}$ ), $\mathrm{Zn}$ (up to $438 \mathrm{ppm}$ ), and to a lesser extent, also enriched in $\mathrm{Cu}$ (up to 154 $\mathrm{ppm}$ ) and $\mathrm{Ni}$ (up to $130 \mathrm{ppm}$ ) relative to average shale. The sample showing the most marked enrichments is from the core containing pebbles of a wide range of meta-igneous and sedimentary rocks and massive sulfides.

\section{Interpretation}

These unfossiliferous sediments of presumed Messinian age accumulated, probably as small clastic wedges, on the west flank of the last rotated rift fault block at the base of the lower Sardinian margin. An evaporitic Messinian paleoenvironment is reflected by occurrence of detrital magnesite, dolomite, anhydrite, and gypsum. Enrichment in Mn, and to a lesser extent of 
Table 2. Major- and trace-element compositions of metalliferous sediments from Site 652 on the lower Sardinian margin. ${ }^{1}$

\begin{tabular}{|c|c|c|c|c|c|c|c|c|c|c|c|c|c|c|c|c|c|c|c|c|c|c|c|c|c|c|c|c|c|}
\hline $\begin{array}{l}\text { Core, section, } \\
\text { interval (cm) }\end{array}$ & $\mathrm{SiO}_{2}$ & $\mathrm{Al}_{2} \mathrm{O}_{3}$ & $\mathrm{Fe}_{2} \mathrm{O}_{3}$ & $\mathrm{MgO}$ & $\mathrm{CaO}$ & $\mathrm{Na}_{2} \mathrm{O}$ & $\mathrm{K}_{2} \mathrm{O}$ & $\mathrm{TiO}_{2}$ & $\mathrm{MnO}$ & $\mathrm{P}_{2} \mathrm{O}_{5}$ & TOT & LOI & $\mathrm{v}$ & $\mathrm{Ba}$ & $\mathrm{Sc}$ & $\mathrm{La}$ & $\mathrm{Nd}$ & $\mathrm{Ce}$ & $\mathrm{Cr}$ & $\mathrm{Ni}$ & $\mathrm{Cu}$ & $\mathrm{Zn}$ & $\mathrm{Pb}$ & Th & $\mathrm{Rb}$ & $\mathrm{Sr}$ & $\mathrm{Y}$ & $\mathrm{Zr}$ & $\mathrm{Nb}$ \\
\hline \multicolumn{30}{|l|}{$107-652 \mathrm{~A}-$} \\
\hline $19 R-4,3$ & 35.04 & 12.09 & 14.98 & 3.74 & 29.41 & 1.82 & 0.52 & 0.44 & 0.75 & 0.11 & 98.92 & 28.1 & 178 & 147 & 2 & 11 & 21 & 44 & 70 & 104 & 35 & 251 & 213 & 12 & 70 & 930 & 16 & 116 & 10 \\
\hline $19 R-5,76$ & 36.15 & 11.76 & 10.85 & 2.97 & 33.18 & 1.53 & 0.75 & 0.56 & 1.20 & 0.22 & 99.21 & 25.5 & 247 & 138 & 5 & 18 & 27 & 52 & 89 & 68 & 35 & 228 & 166 & 8 & 81 & 1122 & 22 & 105 & 13 \\
\hline $19 R-6,125$ & 24.92 & 8.02 & 9.83 & 2.10 & 49.08 & 0.96 & 0.18 & 0.35 & 1.54 & 0.24 & 97.25 & 31.7 & 211 & 98 & - & 2 & 22 & 47 & 62 & 68 & 212 & 278 & 420 & 5 & 58 & 1608 & 23 & 76 & 8 \\
\hline $20 \mathrm{R}-3,143$ & 27.20 & 8.49 & 18.45 & 2.62 & 37.88 & 1.05 & 0.30 & 0.40 & 1.98 & 0.28 & 98.69 & 28.0 & 467 & 103 & - & 8 & 25 & 52 & 66 & 63 & 36 & 468 & 182 & 4 & 55 & 1192 & 18 & 89 & 9 \\
\hline 20R-5, 70 & 22.98 & 7.11 & 20.07 & 2.19 & 42.86 & 0.79 & 0.15 & 0.32 & 1.72 & 0.26 & 98.47 & 29.7 & 405 & 101 & - & - & 12 & 29 & 60 & 72 & 40 & 430 & 155 & 1 & 50 & 1295 & 16 & 74 & 7 \\
\hline
\end{tabular}

Note: Major elements in weight percent oxide; trace elements in parts per million; LOI $=$ Loss on ignition

(analysts: D, James and G. R. Angell)

Table 3. Major- and trace-element compositions of metalliferous sediments analyzed from the Messinian and overlying basin intervals on the lower Sardinian margin. ${ }^{1}$

\begin{tabular}{|c|c|c|c|c|c|c|c|c|c|c|c|c|c|c|c|c|c|c|c|c|c|c|c|c|c|c|c|c|c|}
\hline $\begin{array}{l}\text { Core, section, } \\
\text { interval }(\mathrm{cm})\end{array}$ & $\mathrm{SiO}_{2}$ & $\mathrm{Al}_{2} \mathrm{O}_{3}$ & $\mathrm{Fe}_{2} \mathrm{O}_{3}$ & $\mathrm{MgO}$ & $\mathrm{CaO}$ & $\mathrm{Na}_{2} \mathrm{O}$ & $\mathrm{K}_{2} \mathrm{O}$ & $\mathrm{TiO}_{2}$ & $\mathrm{MnO}$ & $\mathrm{P}_{2} \mathrm{O}_{5}$ & TOT & LOI & $\mathrm{v}$ & $\mathrm{Ba}$ & $\mathrm{Sc}$ & $\mathrm{La}$ & Nd & $\mathrm{Ce}$ & $\mathrm{Cr}$ & $\mathrm{Ni}$ & $\mathrm{Cu}$ & $\mathrm{Zn}$ & $\mathrm{Pb}$ & Th & $\mathrm{Rb}$ & $\mathrm{Sr}$ & $\mathrm{Y}$ & $\mathrm{Zr}$ & $\mathrm{Nb}$ \\
\hline \multicolumn{30}{|l|}{$107-653 \mathrm{~A}-$} \\
\hline $23 R-3,86$ & 33.25 & 10.89 & 10.80 & 2.98 & 36.47 & 1.39 & 0.61 & 0.52 & 1.38 & 0.24 & 98.57 & 26.8 & 215 & 128 & 3 & 21 & 28 & 68 & 76 & 78 & 53 & 372 & 755 & 13 & 75 & 1203 & 20 & 92 & 11 \\
\hline $27 \mathrm{R}-4,26$ & 34.26 & 11.53 & 43.28 & 1.98 & 1.55 & 1.32 & 2.09 & 0.51 & 0.02 & 0.13 & 96.70 & 6.6 & 101 & 392 & - & 15 & 6 & 47 & 100 & 36 & 25 & 50 & 82 & 1 & 98 & 1596 & 16 & 64 & 10 \\
\hline $28 \mathrm{R}-1,40$ & 49.07 & 15.76 & 11.38 & 8.65 & 5.20 & 1.50 & 2.87 & 0.69 & 0.25 & 0.15 & 95.57 & 15.6 & 126 & 240 & 8 & 38 & 26 & 54 & 113 & 46 & 10 & 80 & 11 & 10 & 132 & 186 & 23 & 115 & 14 \\
\hline $28 \mathrm{R}-1,75$ & 38.30 & 12.44 & 24.44 & 3.29 & 7.41 & 1.36 & 2.21 & 0.54 & 0.08 & 0.15 & 90.25 & 11.4 & 106 & 264 & 3 & 31 & 14 & 40 & 96 & 35 & 39 & 56 & 10 & 6 & 103 & 201 & 17 & 89 & 10 \\
\hline
\end{tabular}

Note: Major elements in weight percent oxide; trace elements in parts per million; LOI = Loss on ignition.

(analysts: D. James and G. R. Angell)

Table 4. Major- and trace-element compositions of metalliferous sediments analyzed from the Messinian and basal Pliocene intervals of Site 654 on the upper Sardinian margin. ${ }^{1}$

\begin{tabular}{|c|c|c|c|c|c|c|c|c|c|c|c|c|c|c|c|c|c|c|c|c|c|c|c|c|c|c|c|c|c|}
\hline $\begin{array}{l}\text { Core, section, } \\
\text { interval }(\mathrm{cm})\end{array}$ & $\mathrm{SiO}_{2}$ & $\mathrm{Al}_{2} \mathrm{O}_{3}$ & $\mathrm{Fe}_{2} \mathrm{O}_{3}$ & $\mathrm{MgO}$ & $\mathrm{CaO}$ & $\mathrm{Na}_{2} \mathrm{O}$ & $\mathrm{K}_{2} \mathrm{O}$ & $\mathrm{TiO}_{2}$ & $\mathrm{MnO}$ & $\mathrm{P}_{2} \mathrm{O}_{5}$ & TOT & LOI & $\mathrm{v}$ & $\mathrm{Ba}$ & Sc & $\mathrm{La}$ & $\mathrm{Nd}$ & $\mathrm{Ce}$ & $\mathrm{Cr}$ & $\mathrm{Ni}$ & $\mathrm{Cu}$ & $\mathrm{Zn}$ & $\mathrm{Pb}$ & Th & $\mathrm{Rb}$ & $\mathrm{Sr}$ & $\mathrm{Y}$ & $\mathrm{Zr}$ & $\mathrm{Nb}$ \\
\hline \multicolumn{30}{|l|}{$107-654 \mathrm{~A}$} \\
\hline $26 \mathrm{R}-5,16$ & 21.97 & 7.11 & 13.76 & 03 & 8.89 & 0.95 & & & 2.24 & & 97.89 & & 30 & 125 & - & - & 15 & 40 & 54 & 72 & 58 & 1196 & & & 53 & & & 76 & 7 \\
\hline & 23.16 & 7.98 & 14.98 & 2.58 & 45.10 & 0.9 & 0.31 & 0.3 & 2.0 & 0.29 & 97.80 & 30.1 & 46 & 70 & - & 3 & 19 & 44 & 70 & 93 & 73 & 611 & 1041 & 12 & 56 & 1531 & 19 & 88 & 8 \\
\hline $28 \mathrm{R}-3,37$ & 42.55 & 13.47 & 5.35 & 6.86 & 26.64 & 1.32 & 1.87 & 0.60 & 0.25 & 0.16 & 99.11 & 23.7 & 13 & 625 & 14 & 27 & 32 & 63 & 111 & 75 & 42 & 352 & 130 & 9 & 112 & 468 & 23 & 104 & 12 \\
\hline
\end{tabular}

Note: Major elements in weight percent oxide; trace elements in parts per million; LOI $=$ Loss on ignition. 
Table 5. Major- and trace-element compositions of metalliferous sediments analyzed from the inferred Messinian interval at Holes 656A and 656B on the lower Sardinian margin. ${ }^{1}$

\begin{tabular}{|c|c|c|c|c|c|c|c|c|c|c|c|c|c|c|c|c|c|c|c|c|c|c|c|c|c|c|c|c|c|}
\hline $\begin{array}{l}\text { Core, section, } \\
\text { interval }(\mathrm{cm})\end{array}$ & $\mathrm{SiO}_{2}$ & $\mathrm{Al}_{2} \mathrm{O}_{3}$ & $\mathrm{Fe}_{2} \mathrm{O}_{3}$ & $\mathrm{MgO}$ & $\mathrm{CaO}$ & $\mathrm{Na}_{2} \mathrm{O}$ & $\mathrm{K}_{2} \mathrm{O}$ & $\mathrm{TiO}_{2}$ & $\mathrm{MnO}$ & $\mathrm{P}_{2} \mathrm{O}_{5}$ & TOT & LOI & $\mathrm{v}$ & $\mathrm{Ba}$ & Sc & La & Nd & $\mathrm{Ce}$ & $\mathrm{Cr}_{\mathrm{r}}$ & $\mathrm{Ni}$ & $\mathrm{Cu}$ & $\mathrm{Zn}$ & $\mathrm{Pb}$ & Th & $\mathrm{Rb}$ & $\mathrm{Sr}$ & $\mathrm{Y}$ & $\mathrm{Zr}$ & $\mathrm{Nb}$ \\
\hline \multicolumn{30}{|l|}{$107-656 \mathrm{~A}}$. \\
\hline $4 R-6,31$ & 49.75 & 16.20 & 10.03 & 6.39 & 11.47 & 1.34 & 2.65 & 0.72 & 0.37 & 0.27 & 99.23 & 17.2 & 264 & 381 & 14 & 42 & 30 & 80 & 129 & 76 & 27 & 126 & 36 & 13 & 133 & 218 & 24 & 134 & 16 \\
\hline 54 & 52.79 & 14.26 & 5.77 & 7. & 14.43 & 1.11 & 2.16 & 0.65 & 0.43 & 0.17 & 98.97 & 19.5 & 118 & 608 & 9 & 30 & 26 & 68 & 108 & 55 & 75 & 218 & 18 & 13 & 115 & 166 & 24 & 155 & 14 \\
\hline 4R-6, 74 & 55.27 & 13.86 & 14.17 & 3.24 & 6.74 & 1.59 & 2.52 & 0.62 & 0.53 & 0.20 & 98.78 & 11.0 & 175 & 631 & 7 & 30 & 24 & 48 & 113 & 59 & 92 & 243 & 137 & 11 & 121 & 173 & 20 & 135 & 13 \\
\hline $7 R-1,18$ & 49.30 & 13.61 & 15.11 & 6.10 & 9.46 & 1.14 & 2.21 & 0.61 & 1.26 & 0.19 & 99.04 & 16.5 & 184 & 496 & 13 & 35 & 24 & 64 & 121 & 70 & 71 & 288 & 107 & 11 & 112 & 133 & 22 & 125 & 13 \\
\hline \multicolumn{30}{|l|}{$107-656 \mathrm{~B}-$} \\
\hline $9 \mathrm{R}-1,14$ & 49.91 & 14.95 & 8.75 & 8.49 & 11.94 & 1.21 & 2.33 & 0.68 & 0.78 & 0.17 & 99.25 & 18.9 & 146 & 277 & 19 & 33 & 28 & 68 & 117 & 64 & 42 & 31 & 68 & 12 & 12 & 148 & 24 & 128 & 14 \\
\hline & 44.57 & 12.87 & 25.07 & 5.26 & 6.20 & 1.1 & 2.19 & 0.5 & 0. & 0.25 & 98.8 & 13.3 & 232 & 455 & 8 & 35 & 19 & 59 & 106 & 63 & 111 & 46 & 337 & 11 & 10 & 5 & 0 & 110 & 11 \\
\hline $9 R-3,77$ & 47.39 & 13.25 & 20.61 & 6.2 & 6.54 & 1.18 & 2.12 & 0.59 & 0.6 & 0.24 & 98.80 & 13.7 & 220 & 521 & 6 & 32 & 24 & 63 & 114 & 84 & 189 & 289 & 405 & 15 & 103 & 132 & 19 & 118 & 12 \\
\hline $9 \mathrm{R}-6,105$ & 41.20 & 11.59 & 30.49 & 5.17 & 4.12 & 1.75 & 1.68 & 0.52 & 1.12 & 0.27 & 97.95 & 11.7 & 238 & 276 & 1 & 29 & 12 & 63 & 92 & 130 & 154 & 438 & 1040 & 18 & 71 & 116 & 15 & 97 & 10 \\
\hline
\end{tabular}

Note: Major elements in weight percent oxide; trace elements in parts per million; LOI = Loss on ignition.

'(analysts: D. James and G. R. Angell)

Table 6. Major- and trace-element compositions of mainly metalliferous sediments from within the Messinian succession at Site 652 on the lower Sardinian margin.

\begin{tabular}{|c|c|c|c|c|c|c|c|c|c|c|c|c|c|c|c|c|c|c|c|c|c|c|c|c|c|c|c|c|c|}
\hline $\begin{array}{l}\text { Core, section, } \\
\text { interval }(\mathrm{cm})\end{array}$ & $\mathrm{SiO}_{2}$ & $\mathrm{Al}_{2} \mathrm{O}_{3}$ & $\mathrm{Fe}_{2} \mathrm{O}_{3}$ & $\mathrm{MgO}$ & $\mathrm{CaO}$ & $\mathrm{Na}_{2} \mathrm{O}$ & $\mathrm{K}_{2} \mathrm{O}$ & $\mathrm{TiO}_{2}$ & $\mathrm{MnO}$ & $\mathrm{P}_{2} \mathrm{O}_{5}$ & TOT & LOI & $\mathrm{v}$ & $\mathrm{Ba}$ & $\mathrm{Sc}$ & La & $\mathrm{Nd}$ & $\mathrm{Ce}$ & $\mathrm{Cr}$ & $\mathrm{Ni}$ & $\mathrm{Cu}$ & $\mathrm{Zn}$ & $\mathrm{Pb}$ & Th & $\mathrm{Rb}$ & $\mathrm{Sr}$ & $\mathrm{Y}$ & $\mathrm{Zr}$ & $\mathrm{Nb}$ \\
\hline \multicolumn{30}{|l|}{$107-652 \mathrm{~A}-$} \\
\hline $58 \mathrm{X}-3,63$ & 55.12 & 16.88 & 7.8 & 6.34 & 7.70 & 1.35 & 2.97 & 0.79 & 0.12 & 0.19 & 99.32 & 14.0 & 118 & 163 & 12 & 28 & 29 & 62 & 111 & 59 & 19 & 74 & 14 & 12 & 132 & 121 & 25 & 144 & 16 \\
\hline $58 \mathrm{X}-4,42$ & 55.98 & 17.08 & 12.97 & 3.72 & 3.84 & 1.30 & 3.03 & 0.78 & 0.04 & 0.17 & 98.95 & 10.1 & 135 & 237 & 9 & 37 & 24 & 64 & 126 & 66 & 42 & 89 & 17 & 12 & 136 & 165 & 22 & 144 & 15 \\
\hline $59 \mathrm{X}-1,130$ & 56.40 & 17.08 & 9.93 & 4.93 & 5.58 & 1.14 & 2.86 & 0.79 & 0.09 & 0.19 & 99.03 & 11.7 & 129 & 287 & 11 & 32 & 24 & 61 & 119 & 61 & 21 & 69 & 13 & 11 & 134 & 143 & 25 & 150 & $\begin{array}{l}17 \\
17\end{array}$ \\
\hline $59 \mathrm{X}-1,136$ & 60.11 & 18.22 & 7.38 & 4.42 & 3.95 & 1.26 & 3.20 & 0.84 & 0.06 & 0.18 & 99.64 & 10.2 & 133 & 205 & 12 & 32 & 26 & 61 & 123 & 61 & 6 & 76 & 12 & 14 & 145 & 130 & 25 & 159 & 17 \\
\hline
\end{tabular}

Note: Major elements in weight percent oxide; trace elements in parts per million; LOI $=$ Loss on ignition.

(analysts: D. James and G. R. Angell) 
$\mathrm{Fe}$, in a continental setting points to strongly oxidizing conditions. The enrichment in base metals $(\mathrm{Pb}, \mathrm{Zn}, \mathrm{Cu}$, and $\mathrm{Ni})$ is associated with angular clasts of possible meta-ophiolitic rocks, and, notably, also clasts of massive sulfide ore. Base metal deposits within the basement are thus a possible source of this metal enrichment.

\section{Metalliferous-Looking Laminations in the Messinian Lower Sardinian Margin Succession: Site $\mathbf{6 5 2}$}

There was discussion among the shipboard scientists about the possible origin of orange and reddish colored laminations within mainly terrigenous and evaporitic (sabkha and/or lacustrine) thick successions of Messinian age, which had been cored on the lower Sardinian margin at Site 652 (Figs. 1 and 2). Three intervals, at 27,10 , and $20 \mathrm{~m}$ thick, respectively, contain sporadic, thin, colorful laminations within an overall $84-\mathrm{m}$-thick interval of the Messinian succession. Four samples were analyzed from two cores (107-652A-58R and -59R) (Table 6); these were composed of millimeter-thick red, yellow, and orange limonite partings within grayish and greenish dolomitic and/or gypsiferous fine-grained sandstone.

\section{Mineralogy}

Smear slides of the red bands reveal clay, limonite, and accessory opaque minerals, minor calcite, and traces of quartz.

$\mathrm{X}$-ray diffraction of the stratigraphically lowest samples (Core 107-652A-59R) reveals quartz, with minor dolomite, chlorite, illite, and trace amounts of feldspar, kaolinite, and halite (Table 1). Red and gray claystone is finely interlaminated in Sample 107-652A-59R-1, 135-136 cm (Table 1). The red lamination contains quartz and dolomite, with minor anhydrite and hematite, and trace amounts of kaolinite, chlorite, and feldspar. By contrast, the adjacent gray lamination contains quartz and dolomite, with subordinate chlorite, illite, and trace amounts of kaolinite, feldspar, and anhydrite. The red lamination is richer in hematite and anhydrite and contains no detectable illite relative to the gray lamination. A sample higher in the succession (Core 107-652A-58R) contains quartz, dolomite, subordinate chlorite, illite, feldspar, and minor halite, kaolinite, and mixed-layer clays.

\section{Geochemistry}

All samples are nearly equally siliceous and aluminous and contain similar contents of $\mathrm{K}_{2} \mathrm{O}, \mathrm{TiO}_{2}, \mathrm{P}_{2} \mathrm{O}_{5}$, and $\mathrm{MgO}$ (Table 6). Despite the bright red color, levels of $\mathrm{Fe}_{2} \mathrm{O}_{3}$ are only slightly enriched relative to average shale composition (4.72\%; Turekian and Wedhepohl, 1961). $\mathrm{Fe}_{2} \mathrm{O}_{3}$ in one sample reaches $12.97 \%$ (Core 107-652A-58R, Table 6).

The trace elements confirm a lithogenous composition, with no values departing far from normal shale compositions.

\section{Interpretation}

Red laminae are interbedded with gypsiferous and dolomitic clastic sediments that some believe to have accumulated on a coastal floodplain, or in a lake, marine embayment, or saline sea (Robertson et al., this volume). Possible origins of the red layers are (1) accumulation of wind blown dust, (2) desiccation of rainwater ponds on a floodplain, (3) precipitation from groundwater below the water table, or (4) subaqueous deposition. The undisturbed nature of the fine lamination is consistent with a primary, rather than diagenetic, origin for this red sediment. The low $\mathrm{MnO}$ content indicates these sediments were originally depleted in Mn and/or Mn was removed during diagenesis. The fine laminations do not confirm any evidence of erosion (e.g., scouring) or desiccation (e.g., mud cracking) and the author favors a quiet water-laid origin.

Aeolian influx may be the most plausible explanation for the rare, fine, orange laminations. In this scenario, silt and highly oxidized clays were introduced by desert dust storms, and then settled onto the basin floor. Similar deposits coat modern Middle East sabhkas after dust storms, for example. Aluminosilicates were possibly wind-suspended to a greater extent than calcite, owing to lower density and/or smaller grain size. An alternative, less favored, explanation is that compositional differences existed in the source areas and that this resulted in the accumulation of occasional red layers.

\section{DISCUSSION}

Taking all the Messinian and Pliocene sediments into account, mineralogy and geochemistry show that compositionally similar continental basement rocks supplied all the sites. Majorand trace-element compositions do not obviously discriminate among the different basement terrains identified by petrographic study of the coarser interbedded clastic sediments (e.g., conglomerates and breccias). On the upper Sardinian margin (Site 654 ), provenance was apparently mainly from Paleozoic lowgrade metamorphic siliceous basement and carbonate platform rocks, as those now exposed in Sardinia and Corsica (Sartori et al., 1987; Robertson et al., this volume). By contrast, provenance at Site 652 on the lower Sardinian margin was mainly from Tertiary calcareous sedimentary rocks similar to those now exposed in the southern Apennines and Sicily (Sartori et al., this volume). Furthermore, the breccias that accumulated on the flanks of the de Marchi seamount on the lower Sardinian margin at Holes 656A and 656B were derived from local metamorphosed ophiolite-type rocks and deep-sea sedimentary rocks somewhat similar to outcrops in the Mesozoic Piedmont zone of the mainland to the north (Lemoine, 1980).

Based on coring at Site 132 (Leg 13) in the Tyrrhenian Sea (Fig. 1), Chamley et al. (1976) noted that clay minerals in the Messinian succession are dominated by well-crystallized smectite and chlorite, with both minerals attributed to an evaporitic genesis. Evaporitic sediments were not analyzed in this study and the clay mineral assemblage identified (illite, chlorite, kaolinite, and minor mixed-layer clays) is similar to that of the overlying Pliocene interval (see Chamley et al., this volume). From the Pliocene at Site 132, Chamley et al. (1978) recorded mainly illite, smectite, attapulgite, and kaolinite. Based on limited data from Site 132 (Leg 13), Nesteroff (1973; see also Zemmels and Cook, 1973) earlier noted similar clay mineral assemblages in both the Messinian and Pliocene. Nesteroff also commented on the presence of hematite in the basal Pliocene sediments above the evaporites and suggested derivation from subaerial outcrops soon after Pliocene flooding; he believed that the isolated occurrence of phillipsite was diagenetic. Today's Italian rivers supply mainly mica (illite) and minor chlorite (Quakernaat, 1968). Smectite and mixed-layer clays in the Messinian and Pliocene intervals are attributed to a volcanogenic influx, mainly as volcanic ash and volcaniclastic turbidites.

A striking feature noted in this study is the strong enrichment in $\mathrm{Pb}, \mathrm{Zn}$, and to a lesser extent, in $\mathrm{Cu}$ and $\mathrm{Ni}$, within the ferruginous mudstones associated with "meta-ophiolitic" and other rock clasts at Site 656. Enrichment of $\mathrm{Zn}$ and $\mathrm{Ni}$ was also detected in the Messinian sediments of Site 653 , also on the lower Sardinian margin.

The basal Pliocene sediments analyzed at Sites 652,653 , and 654 , on both the upper and lower Sardinian margins, also are enriched in $\mathrm{Fe}, \mathrm{Mn}, \mathrm{Pb}$, and $\mathrm{Zn}$ relative to the overlying Pliocene nannofossil oozes. However, other heavy metals $(\mathrm{Cu}, \mathrm{Ni})$ exhibit only typical shale values. Selective enrichments in metals might in theory relate to (1) slow selective precipitation from seawater, (2) upward mobilization of metals from lower in the succession, (3) hydrothermal influx, (4) coeval aeolian derivation, or (5) a detrital source. Taken together, the absence of cor- 
responding enrichments in other metals $(\mathrm{Cu}, \mathrm{Ni})$, the paleontological data (Kastens, Mascle, Auroux, et al., 1987), and sedimentary structures provide no evidence that this metal enrichment resulted from slow accumulation from seawater. The underlying Messinian sediments do not include large volumes of organicrich sediments that, conceivably, could have dissolved metals before upward mobilization during diagenesis. $\mathrm{Pb}$ and $\mathrm{Zn}$ hydrothermal ores are common in Tuscany in regions of modern and Late Tertiary hydrothermal activity (e.g., near Pisa, just south of the modern Lardarello hydrothermal field). However, no evidence exists of any contemporaneous hydrothermal activity in the vicinity of the Pliocene Leg 107 sites. Consequently, detrital influx of the trace metals $(\mathrm{Pb}, \mathrm{Zn})$ is the preferred explanation of the metal enrichment, although syndepositional aeolian influx cannot be ruled out.

In this explanatory model, the land surface is considered to have been strongly oxidized during the Messinian time of lowered sea level. Under arid conditions, iron and manganese oxides coated rock and sediment surfaces (i.e., including desert varnish). When the seas flooded at the close of the Messinian, this oxidized material was readily suspended and reworked by currents into the basal clay- and nannofossil-rich deep-sea sediments. A plausible source of $\mathrm{Pb}$ and $\mathrm{Zn}$ enrichment is the basement terrane that supplied the sulfide mineral clasts cored at Site 656 on the lower Sardinian margin. Metals may have been eroded from an exposed rift fault-block in Messinian time; this material may have then been widely disseminated in the basin during the terminal Miocene transgression. Oxide influx later ceased after transgression was complete, and any remaining metal content was diluted with normal pelagic sedimentation.

Despite the spatial association with presumed meta-ophiolitic rock clasts, $\mathrm{Pb}$ and $\mathrm{Zn}$ enrichment is not characteristic of massive sulfide ore bodies within ophiolites (e.g., Troodos, $\mathrm{Cy}$ prus; e.g., Oudin and Constantinou, 1984); $\mathrm{Pb}$ and $\mathrm{Zn}$ enrichment is more suggestive of Kuroko-type deposits associated with volcanic arcs and subduction. For example, black sulfide ore from a type locality in Japan contains $1.41 \% \mathrm{Cu}, 9.4 \% \mathrm{~Pb}$, and $1.87 \% \mathrm{Zn}$ (Oshima et al., 1974; reviewed in Mitchell and Garson, 1981). Were the "meta-ophiolitic" rocks cored at Site 656 derived from the deformed, deeply dissected roots of a volcanic arc related to subduction of the Mesozoic Tethys ocean? A problem, however, is that Kuroko ores are normally interstratified with thick successions of intermediate to acid composition volcanic and tuffaceous sediments, but these types of sediments were not cored at Site 656 .

Alternatively, the association of massive sulfide ore and "meta-ophiolitic" clasts might be coincidental. The ore clasts could instead be derived from sediment-hosted $\mathrm{Pb}$ and $\mathrm{Zn}$ mineral deposits (i.e., Mississippi-type), possibly, for example, similar to the Carboniferous $\mathrm{Pb}$ and $\mathrm{Zn}$ deposits (reviewed by Maynard, 1983). Lead- and Zn-rich solutions might have migrated from deep in the continental crust up faults related to rifting of the Tyrrhenian Sea, followed by subaerial exposure during endMiocene crustal thinning and continental breakup. It may conceivably be significant that the sulfide clasts cored on de Marchi seamount come from the last tilted rift fault-block nearest inferred oceanic crust in the Vavilov Basin (Fig. 1). Thus, leadand $\mathrm{Zn}$-rich mineralization may possibly have exploited the thinned continent-ocean boundary area. Insufficient data exist to decide between possible Kuroko vs. sediment $\mathrm{Pb}$ - and $\mathrm{Zn}$ hosted origins. In either case the $\mathrm{Pb}$ and $\mathrm{Zn}$ anomaly in the basal Pliocene sediments may be explained in terms of erosion of base metal ore deposits exposed on the Messinian land surface.

\section{CONCLUSIONS}

1. Variably metal-enriched sediments occur as local laminations and segregations within Messinian successions of the lower
Sardinian margin at Sites 652 and 653 (respectively). Abundant metalliferous mudstones are also associated with "meta-ophiolitic" rock clasts at Site 656A on the Gortani Ridge on the lower Sardinian margin.

2. The basal Pliocene sediments cored on both the upper and lower Sardinian margin at Sites 652 and 654 and Holes $653 \mathrm{~A}$ and $653 \mathrm{~B}$ comprise reddish and brownish clays up to several tens of meters thick that contrast with the overlying green and gray nannofossil oozes.

3. X-ray diffraction, combined with major- and trace-element analyses, shows that all the sediments were derived from compositionally similar continental basement terrains. At Site 656 , on the lower Sardinian margin, reddish mudstones associated with the "meta-ophiolitic" rock clasts are strongly enriched in $\mathrm{Fe}, \mathrm{Mn}, \mathrm{Pb}, \mathrm{Zn}$, and, to a lesser extent, in $\mathrm{Cu}$ and $\mathrm{Ni}$. Messinian sediments higher on the Sardinian margin at Site 653 are also detectably enriched with $\mathrm{Pb}$ and $\mathrm{Zn}$.

4. The basal Pliocene sediments are strongly enriched in $\mathrm{Fe}$, $\mathrm{Mn}, \mathrm{Pb}$, and $\mathrm{Zn}$ relative to the overlying Pliocene nannofossil oozes. In the model proposed, $\mathrm{Fe}$ and $\mathrm{Mn}$ were oxidized on the Messinian land surface and later reworked into the sea during the Pliocene transgression.

5. The source of the lead and zinc enrichment may be base metal deposits. Possible sources include Mesozoic volcanic-hosted, Kuroko-type, or ?Tertiary Mississippi-type ore deposits. In this scenario, the ores were exposed on tilted rift blocks near the continent/ocean boundary and eroded on the Messinian land surface. The insoluble heavy metal oxides were transported later into the basal deep-sea Pliocene sediments during the transgression that followed Messinian desiccation.

\section{ACKNOWLEDGMENTS}

For assistance with chemical and mineralogical analyses, I thank G. Fitton, G. Angell, and D. James. The manuscript benefitted from comments by D. James, H. Jenkyns, K. Kastens, and J. McKenzie.

\section{REFERENCES}

Chanley, H., de Segonzac, D., and Mélières, F., 1978. Clay mineralogy in Messinian sediments of the Mediterranean Sea. In Init. Repts. DSDP, 42(Pt. 1): Washington (U.S. Govt. Printing Office), 389395.

Colantoni, P., Fabbri, A., Gallignani, P., Sartori, R., and Rehault, J. P., 1981. Lithologic and stratigraphic map of the Italian Seas. Cons. Naz. Ricerche Publ., Map 4.

Fitton, J. G., and Dunlop, H. M., 1985. The Cameroon line, West Africa and its bearing on the origin of oceanic and continental alkali basalt. Earth Planet. Sci. Lett., 72:23-38.

Gennesseaux, M., Rehault, J.-P.. Thomas, B., Colantoni, P., Fabbri, A., Lepvrier, C., Mascle, G., Mauffret, A., Polino, R., Robin, C., and Vanney, J., 1986. Resultats des plongées en submersible Cyana sur les blocs continentaux bascules (mer Tyrrhenienne centrale). Comp. Rendus Seances de l'Acad. Sci. (Paris), Ser. II, 302:785-792.

Hardie, L. A., Smoot, J. P., and Eugster, H. P., 1978. Saline lakes and their deposits: a sedimentological approach. In Matter, A., and Tucker, M. E. (Eds.), Modern and Ancient Lake Sediments. Spec. Publ. Inst. Assn. Sedimentol., 2:7-41.

Heezen, B. C., Gray, C., Segre, A. G., Zarudski, E.F.K., 1971. Evidence of foundered conntinental crust beneath the Central Tyrrhenian Sea. Nature, 229:327-329.

Hsü, K. J., Montadert, L., Bernoulli, D., Cita, M. B., Erickson, A., Garrison, R. E., Kidd, R. b., Mélières, F., Müller, C., and Wright, R., 1978. History of the Mediterranean salinity crises. In Hsü, Montadert, et al., Init. Repts. DSDP, 42(Pt. 1): Washington (U.S. Govt. Printing Office), 1053-1078.

Kastens, K. A., Mascle, J., and Shipboard Scientific Party, 1988. ODP Leg 107 in the Tyrrhenian Sea: insights into passive margin and back-arc basin evolution. Bull. Geol. Soc. Am., 100:1140-1156.

Kastens, K. A., Mascle, J., Auroux, C., et al., 1987. Proc. ODP, Init. Repts., 107: College Station, TX (Ocean Drilling Program).

Lemoine, M., 1980. Serpentinites, gabbros, and ophicalcites in the Piedmont-Ligurian domain of the western Alps: possible indicators 
of oceanic fracture zones and of associated serpentinite protrusions in the Jurassic-Cretaceous Tethys. Arch. Sci. Geneve, 33:103-115.

McKenzie, J. A., Hsü, K. J., Schneider, J. F., 1980. Movement of subsurface waters under the sabkha, Abu Dhabi, UAE, and its relation to evaporative dolomite genesis. In Zenger, D. H., Dunham, J. B., and Ethington, R. L. (Eds.), Concepts and Models of Dolomitization. Soc. Econ. Paleo. Miner., Spec. Publ., 28:11-30.

Maynard, J. B., 1983. Geochemistry of Sedimentary Ore Deposits: Berlin-Heidelberg (Springer-Verlag), 1-149.

Mitchell, A.H.G., and Garson, M. S., 1981. Mineral Deposits and Global Tectonic Settings: New York (Academic Press), 1-405.

Nesteroff, W. D., 1973. Distribution of fine-grained sediment component in the Mediterranean. In Ryan, W.B.F., Hsü, K. J., et al., Init. Repts. DSDP, 13: Washington (U.S. Govt. Printing Office), 666669.

Oudin, E., and Constantinou, G., 1984. Black smoker chimney fragments in Cyprus sulphide deposits. Nature, 308:349-353.

Oshima, T., Hashimoto, T., Kamono, H., Kawebe, S., Suga, K., Tanimura, S., and Ishikawa, Y., 1974., Geology of the Kosaka Mine, Akjita Prefecture. In Ishihara, S. (Ed.), Geology of Kuroko. Ore Deposits. Soc. Mining Geol. Japan, Spec. Publ., 6:89-100.
Quakernaat, J., 1968. X-ray analyses of clay minerals in some recent fluviatile sediments along the coast of central Italy. Alphen aan de Rijn, Vis-druk (Amsterdam), 1-105.

Sartori, R., Mascle, G., and Amaudric du Chaffaut, S., 1987. A review of circum-Tyrrhenian regional geology. In Kastens, K. A., Mascle, J., Auroux, C., et al., Proc. ODP, Init. Repts, 107: College Station, TX (Ocean Drilling Program),37-64.

Shearman, D. J., 1982. Evaporites of coastal sabkhas. In Dean, W. E., and Schrieber, B. C. (Eds.), Marine Evaporites. Soc. Econ. Paleontol. Mineral., Short Course, 4:6-42.

Turekian, K. K., and Wedhepohl, K. H., 1961. Distribution of the elements in some major units of the earth's crust. Bull Geol. Soc. Am., 72:175-191.

Zemmels, I., and Cook, H., E., 1973. X-ray mineralogy of selected samples from the seafloor of the Northeast Atlantic and Mediterranean Sea. In Ryan, W.B.F., Hsü, K. J., et al., Init. Repts. DSDP, 13: Washington (U.S. Govt. Printing Office), 605-665.

Date of initial receipt: 2 September 1987

Date of acceptance: 2 December 1988

MS 107B-191 